Case Reports

\title{
Understanding the Relationship between Aquaculture and Poverty: The Case of Gurudaspur, Natore
}

\author{
Saman Saad, Raisa Bashar, Farah Yeasmin and Nazmul Ahsan Khan \\ Department of Environmental Science and Management (ESM), \\ North South University, Plot \# 15, Block \# B, Dhaka-1229, Bangladesh
}

\author{
Article history \\ Received: 21-07-2017 \\ Revised: 06-12-2018 \\ Accepted: 6-02-2018 \\ Corresponding Author: \\ Saman Saad \\ Department of Environmental \\ Science and Management \\ (ESM), North South \\ University, Plot \# 15, Block \# \\ B, Dhaka - 1229, Bangladesh \\ Email: saman_saad01@yahoo.com
}

\begin{abstract}
Aquaculture is perceived as a source of income and economic raise in several small towns and villages of Bangladesh and Gurudaspur of Natore region is no different. From the 1990s onward it brought about a great economic boost. However, in the last decade and at present, several negative externalities of this practice have started to surface, including severe water-logging (after flooding), depletion of water resources and economic losses. These issues can be attributed to unplanned fish pond-cutting and unrestricted entry into the aquaculture business. Based on this background, this study tried to capture the change in the economic condition of people associated with small-scale aquaculture, through focused group discussions, participatory rural appraisal and individual interviews, with the owners and workers about their past and present incomes, before and after they started fish-farming, in two villages of Gurudaspur, namely Brigarila and Moharajpur. Additionally, basic GIS analysis was performed to analyze the changes in land use patterns and their impacts on the surroundings. The authors' observations about the present status of the owners of the fish-farms were also noted, along with some recommendations based on the local governments' advice and initiatives to stop new pond-cutting (which is not seeing much success). There is no doubt that even though aquaculture in Gurudaspur saw a positive inception, its progression was flawed and, consequently, the mentioned problems are becoming bigger as days go by. Although, Moharajpur's water-logging problem (some of which still exists because much needed canal building is ongoing) is not that severe (due to higher years of experience and hence more development in this sector), Hence, Brigarila's condition is already very dire and worsening day by day. It is the conclusion of the authors that Gurudaspur's aquaculture practices are unplanned and hence, unsustainable and will soon not yield any more profits, leaving several hundred in an economic downturn, if proper drainage systems and laws are not implemented, coupled with relevant training and education.
\end{abstract}

Keywords: Aquaculture, Gurudaspur, Natore, Fish-Farming, Water-Logging

\section{Introduction}

The fisheries resources play a significant role in fulfilling the demand for animal protein and socioeconomic development of Bangladesh. It is reported that the fisheries sector contributes to about $9 \%$ of the Gross Domestic Product (GDP) and employs about 9\% of the labor force of the country (Bayes, 2015). The article also mentions that according to a study by the World Bank, worldwide demand for fish is expected to increase from the present 2.2 million metric tons to somewhere between 5.5 and 8 million metric tons by the year 2025; here, Bangladesh will have a large role to play. Therefore, aquaculture could be used as a tool to contribute to food security, as well as economic and social inclusion for some of the world's poorest populations (Jahan et al., 2015).

Fish farming in ponds (freshwater) is one of the fastest growing economic activities of the country and with proper support it can contribute a lot to the economy of the country (Faruk et al., 2004). Natore is one of the districts that has seen success in freshwater fish farming practices also providing employment for people in that area. The study of the fish farming practices in such regions would be helpful in determining how to promote aquaculture practices that are sustainable and would not be harmful for the environment. 
However, exploitation can lead to negative consequences and there is now enough evidence to believe that several villages in this aquaculture-rich region are facing environmental problems, most notable of which is the prolonged water logging in the area. This scenario coupled with the commencement of economic losses due to a positive inception has led to subsequent flaws in the production process. Before such regions are left in a dire situation it is important to identify the causes of these problems and implement solutions to mitigate and later eradicate the issues through participatory and regulatory approaches.

\section{Background and Rationale}

The region of Gurudaspur under the Nazirpur and Moharajpur Unions is an economically stable one with widespread aquaculture practice. In Gurudaspur there were 1770 and 2000 fish farmers in 2010 and 2011 respectively (MOP, 2013). Aquaculture here is practiced in a semi-intensive way where the production varies from 1.5-4.0 MT/Ha. Carp polyculture is the most practiced freshwater aquaculture activity and other commonly cultured fish species include Rui, Mrigal, Katla, Mirror carp, Pangash.

Past literature states that from the turn of the 1970s and especially after the 1990s advances, in aquaculture and the shift from being a primarily agrarian region to a primarily aquaculture one has improved the residents' socio-economic status at every level. However, this was not always the scenario; the economic condition of the residents, before the change, was very poor and many families would not be able to earn enough to eat three meals, let alone invest to expand their incomes. So, it would not be wrong in saying that aquaculture was the main driving force that brought about poverty alleviation in the region. The mud/tin houses were replaced by brick and mortar ones which were often two-storied high now, women of the house no longer worked hard for household chores like bringing water from faraway tube wells (some could even afford maids) and there was plenty of income to consume necessary items, luxury goods and also invest to expand the aquaculture business.

However, at present several issues have surfaced due to the extreme intensity of fish-farming and although, smaller businesses were ousted by the larger ones and those who were former owners of smaller fish-farms now work at the larger farms, there are still too many farms in a place too small: Hence, economies of scale has long run out. Problems now include flooding and subsequent water-logging, depletion of water resources, loss of agricultural land and fruit orchards (and related biodiversity) and economic losses. Problems such as loss of groundwater level and health issues are expected to surface soon too. These issues can be attributed to unplanned fish-pond cutting (construction of aqua cultural ponds) and unrestricted entry into this business. Hence, this research was initiated in an attempt to identify the problems and subsequent effects that have arisen due to unplanned and unmonitored pond-cutting and find corresponding solutions to mitigate the impacts.

\section{Literature Review}

There is significant literature on the positive effects of aquaculture on the economy of a region, including Natore. However, the negative effects on the local environment and potential drawbacks in terms of monetary implications are rare.

To start off, Faruk et al.'s (2004) paper, which analyzed the aquaculture conditions of five districts of Bangladesh (one of which was Natore) with the involvement of 500 farmers overall, stated that among all the surveyed areas, Natore has the best (i.e., lowest incidences of) record of fish diseases. It is noted in this study that government intervention or knowledge is lacking in Natore's villages and there is minimum involvement of the NGOs, but medicine companies are there to help the farmers with fish health management. The authors also observed similar managerial issues from the side of the government and found little or no mention-worthy incidences of fish diseases; NGOs were rarely mentioned if ever.

In contrast, according to Uddin and Akhi's (2014) interpretation of results after a study of seven villages under Ishwarganj upazila of Mymensingh district and eight villages were selected under Madhupur upazila of Tangail district, concluded that NGO intervention actually improves the profits and employment opportunities from aquaculture and helps mitigate problems associated with aquaculture through experience sharing and knowledge distribution. Furthermore, they found out that agricultural practices were indeed less profitable than aquaculture and hence, it is a smart choice for many villagers to improve their socio-economic status, as was found in the study at hand as well.

Additionally, in answer to the question of whether aquaculture is truly pro-poor or not, Toufique and Belton's (2014) study found out that this practice is more beneficial to the comparatively wealthier land owners, but also evidently reduced the income inequality in the regions studied through employment in their practices. However, the opportunity tended to be more geographically concentrated, than any other parameters examined. It was also found that the main reason for success both from the demand and supply side of this practice is that rapid expansion of commercial aquaculture brought down prices of fish with increasing supply thus resulting in increased fish consumption by 
the extreme and moderate poor and also those in rural areas. The authors therefore state that aquaculture has the most potential to benefit the poor, through increased 'fish affordability' via reduced prices: From 2000 to 2005 consumption of farmed fishes increased $64 \%$ for the extreme poor. Viable capture fisheries would complement pro-poor aquaculture growth according to the paper and so, just like the recommendations of the study at hand, policies to promote both practices sustainably were recommended.

All the papers analyzed have a common conclusion that aquaculture, specifically intensive, brings in higher profits than agricultural practices. It was further found that NGOs as well as local government often support aquaculture practices in rural and semiurban regions. However, there seems to be a lack of knowledge as to how to make these practices sustainable. This is where the authors' study on Gurudaspur can add important findings about the negative impacts of aquaculture to the literature.

\section{Methodology}

The places of study included Brigarila and Moharajpur (two villages of Gurudaspur) and the targets were the fish farmers (pond-owners and workers). 40 surveys from Brigarila (4 discarded) and 15 from Moharajpur (3 discarded) were considered for analysis. Ages of the interviewees ranged from 26-60 and samples were made as random as possible as per income levels, education/training levels, owners to workers ratio, farm size, etc. However, we do not have the exact numbers of fish farmers, but according to a local newspaper which had references from Natore District Fisheries Office, the number of total fish farmers in the whole district was 18,038 in 2014. In Gurudaspur sub-district, there were 2000 and 1770 fish-farmers in 2011 and 2010, respectively. Also, the area had 1472 ponds in 2010/2011 (Flowra et al., 2013).

Participatory rural approach such as focused group discussions were used and individual interviews were the main methods of data collection along with observations of the authors and also the inspection of the ponds and surrounding areas of the villages. Local help was acquired to gain access, build rapport with the locals and to eliminate bias that might result from the difference in opinions of the people and also, the behavior of the respondents (outliers were averaged; the introverts were given chances to speak up and interviewed separately many-a-times; outspoken people were asked to give others the floor). Interviews were also conducted of officials from the local Department of Fisheries and Department of Environment offices.

The study design of this paper could be considered a mixed type of research with different methods to find the ultimate objectives. The types of study included.
Participatory Rural Appraisal via Focused Group Discussion

The study focused on talking with the people of the village to find out about their lifestyles and the types of problems that they face or the benefits they get from fish farming and also the villagers views on what they think can be done for sustainable fish farming was also considered.

There were two focused group discussion with the general people of the village that included both fish farmers and non -fish farmers. The information from this discussion was mostly about the environmental impacts of fish farming, the changes in the villages noticed in recent years and their views on fish farming.

\section{Close-Ended Questionnaire}

One-on-one interviews were done with the fish farmers using questionnaires that tried to find the change in the socio-economic condition of people associated with small-scale aquaculture practices. Information on their past and present incomes, before and after starting fish farming and information on land use change.

\section{Key Informant Interviews}

A District Fisheries Officer and also a District Statistical Officer in Natore were visited to interview as key informants about the status of fish farming practice in Natore and specifically Gurudaspur.

\section{Authors' Observations}

The authors' observations of the status of the fish farmers homes, the condition of the village and the ponds and such are also noted in the discussions

\section{Secondary Sources}

Information on fish farming from the Bangladesh Bureau of Statistics and related research done on Natore and other regions of the country are also taken into account.

Furthermore, GIS/temporal analysis was performed through the image collection step where high resolution satellite images of the area were downloaded from Google Earth of the years 2001, 2011 and 2016. Next, data preparation was done using the downloaded images which were geo-referenced to analyze them with known co-ordinate system. First off, they were transformed to the Universal Transverse Mercator (UTM) map projection system, with datum D_WGS_1984. Later, the study area was extracted according to previously created and projected shape file based on satellite images. For this operation, extraction tool of ArcGIS 10 was used. In the last step, data digitization through supervised classification method was done, using polygons that represent distinct sample areas of the different land use types to be classified (training 
samples). Four specific classes were taken for the classification; pond area, land area, area covered by trees/orchards and miscellaneous. Area of each category was calculated by using pixel counts.

Timeline of the study - the timeline of the study consisted of a week in late October, between the $21^{\text {st }}$ and $25^{\text {th }}$ of October 2016 . The studies were conducted during that time while the author had boarding in Brigarila (which was the main focus of the study area). In Bangladesh, monsoon stays till the end of September and October to March is mainly the dry seasons. Due to that the water logging phenomenon was not much observed, which is common in monsoon (especially during July). Still water logging was observed at a couple of land areas which were lower than the surrounding areas, where water was still collected for a while. Flood becomes an issue during monsoon usually from April/May to October.

Loamy soil is predominant in this area. The annual average precipitation rate of Natore is $1862 \mathrm{~mm}$ (MOP, 2013). The two sites share similar elevation (Source: Google Earth Pro) and the depth of the tube wells are 100-120 feet. The major source of water for the ponds is groundwater which is brought over using motorized pumps via submergible pipes.

\section{Results and Discussion}

\section{Inception}

\section{Motivation for Starting Fish Farming}

In Moharajpur $50 \%(\mathrm{~N}=6)$ of the people said that they chose to be involved in fish farming, because it produced more income than agriculture. The other 50\% $(\mathrm{N}=6)$ said that it was kind of the most popular job in the village and almost everyone they knew were fish farmers, which meant that they chose this profession, because of the higher income opportunities as well as going with the trend of most of the people in the villages being fish farmers. In contrast, in Brigarila most people responded with more than one reason. However, similar to Moharajpur, the most popular reason was that these people believed that aquaculture could generate more income than agriculture. They were motivated seeing their neighbors earn so much profit from fish farming. Another reason for changing professions was also the water logging problems in the area which increased with increase in ponds. This also produced fewer turnovers from crop production and waterlogged agricultural lands which forced them to change professions as that land could not be used to grow crops anymore. When a certain area was cut into a pond this would affect the surrounding land area of that pond. As a result, if there was any agricultural land in that area, the crops were destroyed due to water seepage from the pond and in turn that land could not be used for agricultural practices anymore. As a result, the owner would use that land for fish farming since agriculture was not possible anymore. Water logging also affected the fruit gardens which were also turned into ponds. Amongst the people surveyed in Brigarila, one person did say that he picked up fish farming from his father; it was kind of a family business.

\section{Previous Occupation of the Fish Farmers}

In Brigarila $86 \%(\mathrm{~N}=31)$ of the people surveyed were agricultural farmers before getting involved in fish farming. Whereas, in Moharajpur only two people were involved in agriculture farming and $58 \%(\mathrm{~N}=7)$ of the respondents did not have any other occupation before starting fish farming, which was their first. One other person in Moharajpur was a teacher who also started fish farming due to its popularity in the area and has been involved with it for over 20 years, while also being a teacher in a college in the area. Another person in Brigarila is also a teacher at a school in the village and joined fish-farming fairly recently for an extra source of income. In Moharajpur fish farming seemed to be the most popular profession and one respondent said that if you lived in the village that was the only profession you could choose. The higher number of people in Moharajpur with no previous occupation accounts for that statement, after finishing their studies most people chose being a fish farmer. Whereas in Brigarila, the higher number of agricultural farmers turned fish farmers accounts for the authors' presumption of the vast quantity of land use change in the village. Fish farming is a more recently popular profession in the village in about the last decade or so.

\section{Previous Land Use}

Before being cut into ponds the lands of the people surveyed in Brigarila were agricultural lands. This was also the case in Moharajpur, but $25 \%(\mathrm{~N}=3)$ people in Moharajpur did say that their land was pastureland before it was cut into ponds and used for fish farming. Such vast quantities of agricultural lands prove the fertility of these lands and that agriculture was the main driving source of income before learning about the benefits of fish farming (Fig. 1).

\section{Positive Inception to Flawed Progression}

\section{Improved Socio - Economic Status}

Almost $100 \%(\mathrm{~N}=48)$ of all the farmers surveyed across both the villages said that their socio-economic status had improved after they switched to/started aquaculture practices. Indicators of improved social and economic status included. 


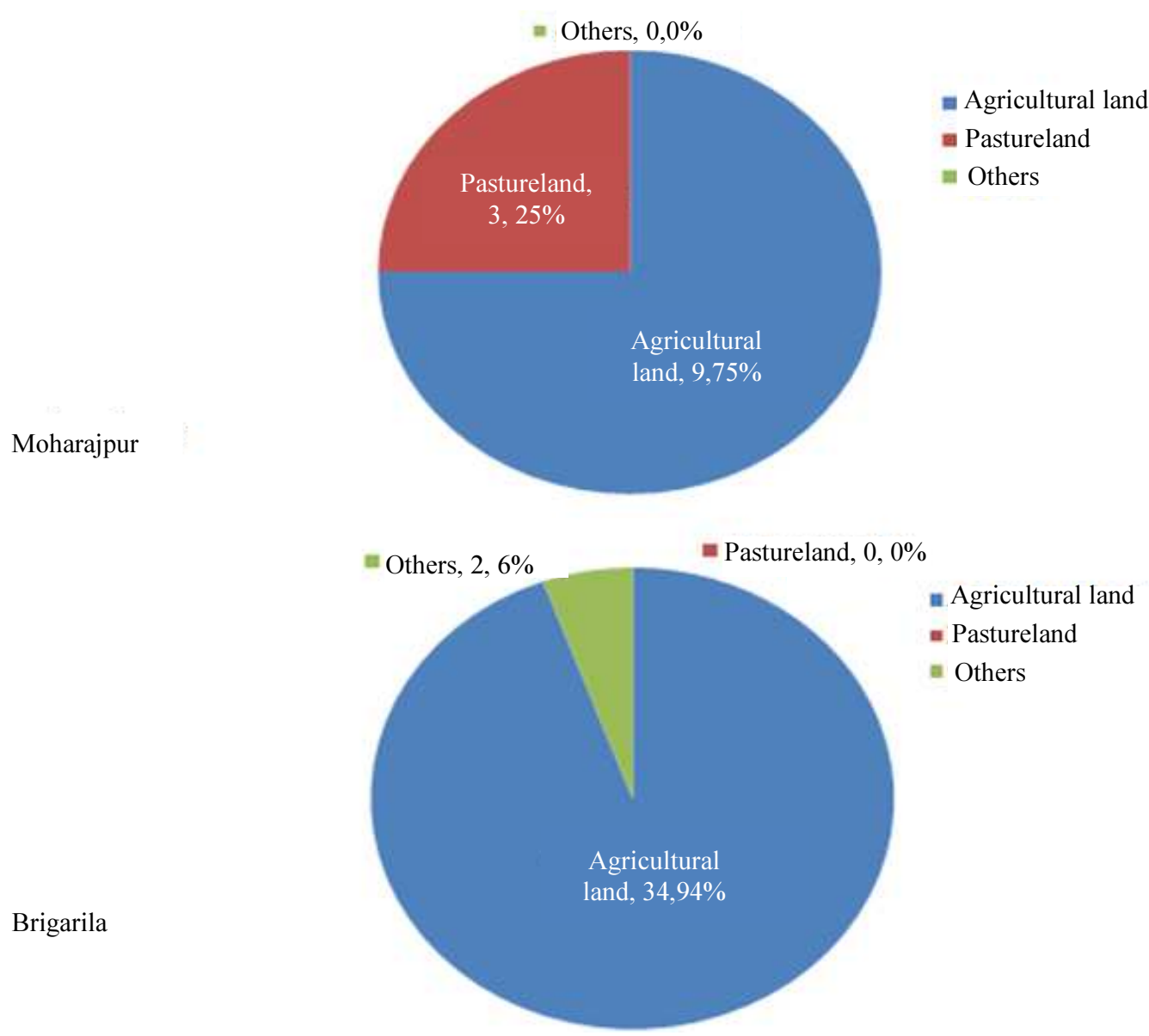

Fig. 1: Land use before starting fish farming in Moharajpur and Brigarila, respectively

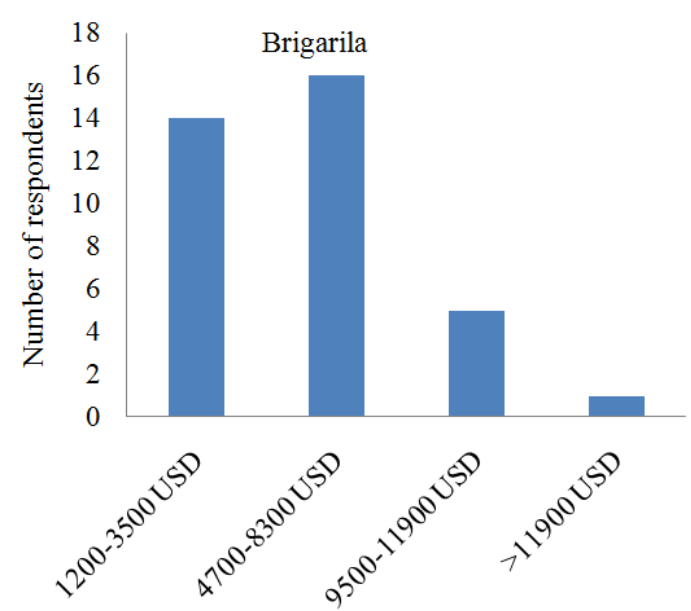

Income (in USD)

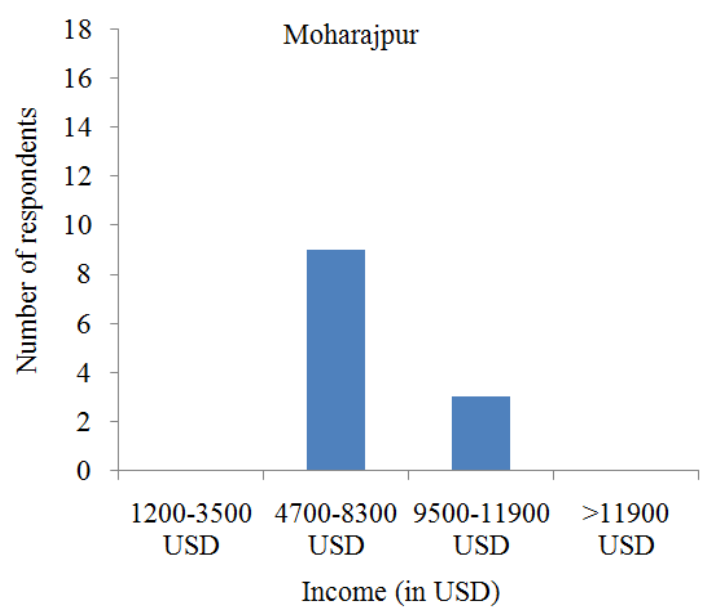

Fig. 2: Respondents' income in 2016

\section{Housing}

Surveyed farmers confirmed that many, especially the pond owners, switched to 'pacca' (concrete), sometimes duplex, homes after profits started coming in from aquaculture; luxury items were also added from the same source; almost all houses were semi/fully pacca $(100 \%(\mathrm{~N}=$ 12) in Moharajpur, $61 \%(\mathrm{~N}=22)$ in Brigarila). 


\section{Average Annual Income}

The biggest indicator; after aquaculture's introduction poverty alleviation was very evident as those who did not earn even a few thousand BDT previously, now earned in over 100,000 BDT; from 11.9 USD to around USD11900 (Fig. 2).

\section{Drinking Water Facilities}

All of the households had deep tube - wells that they used for fresh water purposes

\section{Daily Die}

Was well-maintained, because in Brigarila almost everyone, $87.5 \%$ of the people surveyed responded that they consumed fish 5/6 days in a week; the results in Moharajpur was also higher, all of the people surveyed responded that they consumed fish more than half of the days in a week

\section{Alternative Source of Income}

About $75 \%$ participants in Brigarila and over 50\% from Moharajpur were involved in alternate livelihoods, mostly agriculture; this generated even more income and contributed to poverty alleviation.

\section{Situation of Women}

The wives of aquaculture business owners had a lot more leisure now as they had less to do to help their husbands now then when they were involved in agriculture. Also, some of the bigger and richer households could afford maids. The maids were usually women (wives/daughters) of men who worked under the owners of the ponds, giving them (the maids) an opportunity to contribute to their poorer (than the owners) households. In both the villages, women's participation in fish farming was non - existent. No women were found actively participating in fish farming.

\section{Environmental Impacts}

Water-logging: Affects livelihoods and even health. Pond construction changes the land classes. The adjacent cultivable lands are affected first due to ponds. There is no proper drainage system for discharging water and unplanned land alteration creates canal stagnation and narrows down water paths to river. Another reason of siltation is soil erosion and damage of pond dykes. Since, the area has less vegetation cover therefore rainwater and floods carry away the top soil from the ground.

Agricultural Land Loss: Mainly due to water-logging, there was a significant amount of cropland lost. The loss was approximately 19\% (From 2600 acres in 2001 to 2100 acres in 2016).

Biodiversity Loss: Due to pond cutting and disappearance of trees, less migratory birds are seen in the villages according to elders who have been residents for very long. However, no counting efforts were ever taken by officials.

Increase in banana/date/beetle nut orchards: This occurred, because the dykes of the ponds were planted with the same type of trees, namely banana trees and some date trees. So, even though there was an $87.5 \%$ (from 800 acres in 2001 to 1500 acres in 2016) increase in orchard area, the biodiversity decreased due to the planting of the same species of trees.

Lack of Monitoring: Even after advice from government against pond-cutting, it still continued as no follow-up is done.

Health Effects due to Contamination: During the FGDs many of the young farmers pointed out that the workers who sometimes had to get into the ponds (for various purposes like feeding, maintenance works or catching fish) faced itching, irritation in eyes and temporary skin inflammation as they come into contact with the inorganic substances (like fertilizers) used to keep up the yield of the ponds. Also, the ducks were kept away from swimming in these waters as the fleas present in their feathers increased after they had bathed in these ponds and the fleas in turn caused harm to the fishes present. Furthermore, some talked about rare incidences of contamination of nearby lands when the water from the aquaculture ponds overflowed into them and were waterlogged for a long time.

Surprisingly, $75 \%$ participants from Brigarila and $83 \%$ from Moharajpur were aware that excess pondcutting and unsustainable aquaculture is taking Gurudaspur towards demise. These conclusions were reached from the observations of the villagers mainly found out through focused group discussions. So, the conclusion to be drawn here was that although initially profits were high and that brought about an economic boost across Natore, at present and in the near future there are/will be large negative externalities.

\section{Past, Present and Future Changes in Land Use}

To predict near future land use pattern of the study area of Gurudaspur, present and 15 years prior land cover pattern have been examined (Fig. 3). The land cover has been classified into four groups and they are land area, pond area, area covered by tree and orchards, miscellaneous.

Figure 3 and 4, derived via geo-referencing and the use of ArcGIS show major amount of land in the study area was used for crop cultivation, although land availability for cultivation decreased gradually between 2001 and 2016. Both the maps and graphs also show gradual increase of ponds from 2001 to 2006 and a dramatic increase from 2011 onwards until 2016. Also, land covered by orchard and trees seemed stable from 2001 to 2011, but increased gradually from 2011 
onwards. Similar trends in ponds and orchards/tree areas can be attributable to the fact that farmers use the boundary of ponds for tree plantation, especially banana and dates. Decrease of miscellaneous land could be linked to increase of area under orchard and trees category.
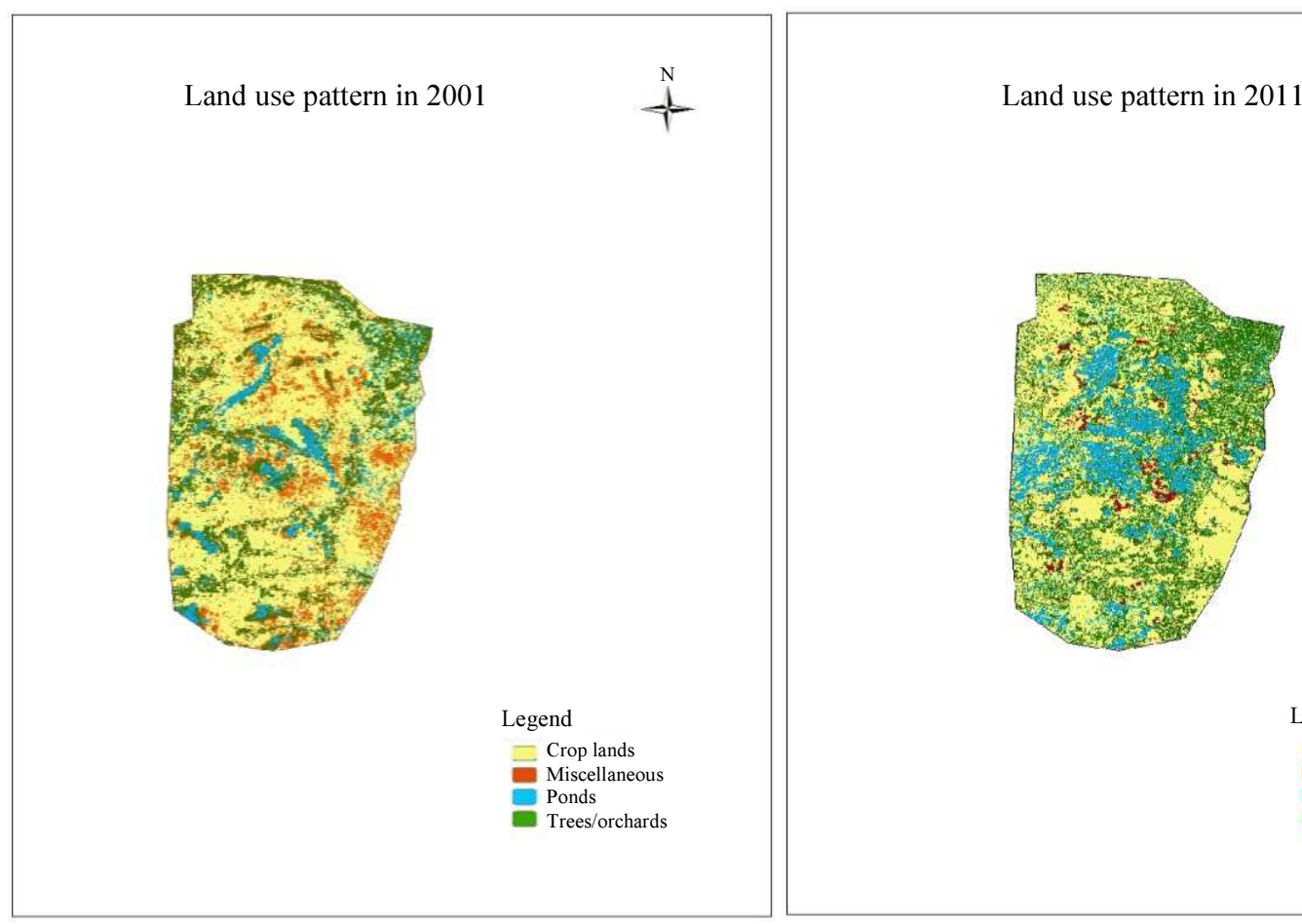

Legend

E Crop lands

Miscellaneous

Ponds

Trees/orchards

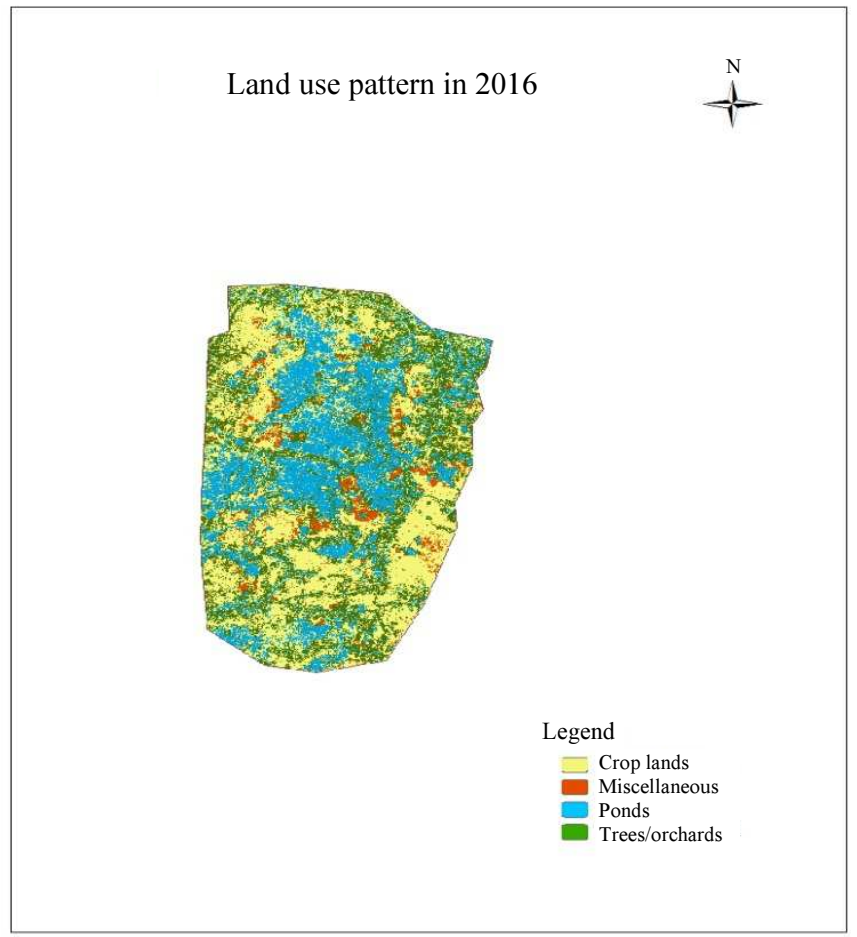

Fig. 3: Changes in land use patterns of Gurudaspur in 2001, 2011 and 2016 using Google Earth 


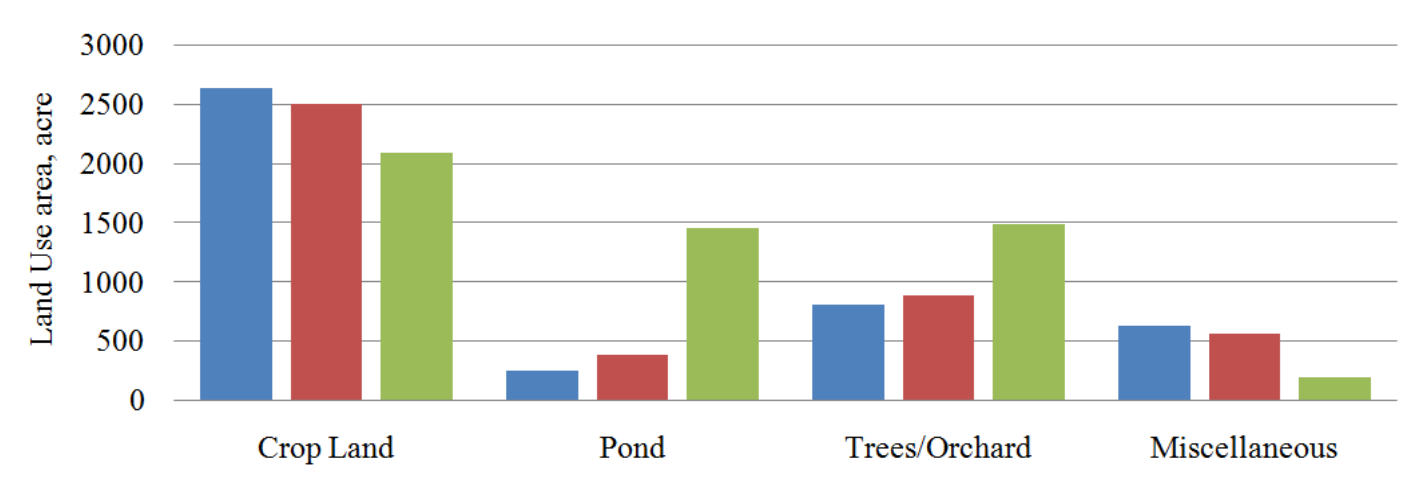

घ2001 $\square 2011 \square 2016$

Fig. 4: Change in four types of land use pattern from 2001, 2011 and 2016 derived

\section{Predicted Future Impacts}

\section{Loss of Local Biodiversity}

Trees in fruit gardens and the local tree biodiversity are dying due to intolerance from large amounts of water in soil and water-logging. Also trees are being cut down to make room for ponds and only banana trees are planted on the small areas surrounding the ponds. This is because only banana trees do not shed leaves that would fall into the pond. Also, a loss in bird diversity is observed due to fewer trees in the area, although some predatory birds are more common because of the fishes available. Although, several literatures including an article by James (2009) titled, "Aquaculture Production and Biodiversity Conservation" highlights the increase in fish biodiversity due to aquaculture, they also state about the loss of plants (especially herbs) and bird biodiversity.

\section{Further Water-Logging}

Incidences of water-logging during heavy rain showers in the monsoon season can last up to the entire season and if the pond-cutting rate does not go down this might become a permanent phenomenon.

\section{Health Issues}

If water-logging persists, water-borne pests and diseases will be on the rise, such as, the increase in mosquitoes in the area which could lead to mosquitoborne illnesses.

\section{Scarcity of Water in Dry Seasons}

Combination of rainwater and ground water is the main source of fish-farming. People use submergible pumps and deep tube wells (which are run either by electricity or diesel) to extract water from groundwater sources to fill in the ponds (especially in dry seasons) and deep tube wells, low lift pump and shallow tube wells are used for increasing households and irrigation requirements, predicted water-shortage could be a huge problem in the future. The deep tube wells are installed at around 120 feet to 150 feet deep down.

\section{Loss of Agricultural Land}

One of the main reasons that people in Brigarila switched to aquaculture was that agricultural lands' yields were going down during intense water - logging; this phenomenon is still persistent and continues to destroy croplands, but on a more larger scale due to increase in pond cutting.

\section{Economic Losses}

If the unplanned pond0cutting continues, fish resources will start dying as they will face constant waterlogging, diseases and even lack of water (especially if ground water sources go down). As is known from talking to the fish farmers that production costs for maintaining fish farming practices are increasing with increasing prices for feed, chemicals, fingerlings, fertilizers etc.; whereas the cost of the such freshwater fishes are reducing with increasing supply of fish. Additionally, unstable temperatures further decrease yield. This could result in huge economic losses for the community in the future. Hence, the poverty alleviation brought about by the positive inception of aquaculture will bring about a local economic downturn due to its flawed progression.

\section{Comparative Study: Brigarila Vs. Moharajpur}

From authors' observations and using opinions of the local government officers a comparative study was created to analyze the differences in success of aquaculture practices between the two areas studied. The main difference between the two villages can be seen in the average number of years people have been practicing aquaculture in these two villages. The surveyed fishfarmers in Moharajpur have been employed in aquaculture for a much longer time than the people in Brigarila; in Brigarila fish farming through pond cutting has gained popularity mostly in the last decade or so only. 
In addition, zero percent of the people surveyed in Moharajpur did not have any occupation before joining fish farming (this could also be a sampling error). The people in the village said that fish farming is the most popular occupation and more than half of the village population was involved in fish farming. They also said that it was the most suitable career to choose if they chose to stay in the village; whereas $100 \%$ of the fish farmers surveyed in Brigarila had an occupation before starting fish farming and $86 \%$ people were involved in agricultural practices. Furthermore, another trend seen in the fish farmers in Brigarila was, some of them worked as labors in Middle - East and came back with a lot of money that they decided to invest in fish farming. Additionally, on average, the people in Moharajpur were more educated. In Brigarila $58 \%$ of the respondents did not finish school whereas in Moharajpur $84 \%$ of the respondents studied up to Higher Secondary Certificate (H.S.C.) or above, whereas, only $22 \%$ of the respondents in Brigarila said that they did not receive any proper education and some could only just about sign their names (Fig. 5). So, it can be concluded that the area that had higher levels of education and longer experience in fish farming was more successful; in this case Moharajpur, because its management and plans were more strategic. While in Brigarila it was also the case that most educated people went to the cities for education and found better employment opportunities there. Hence, environmental impacts associated with aquaculture's externalities are lower in the former.

The fish farmers in Moharajpur are involved in fish farming on a much larger scale; they have more ponds that are larger and have a lot more knowledge as a result of $83 \%$ of the surveyed people having training in fish farming, while in Brigarila some people just about cut ponds into the small amount of land that they had and they depend on friends, neighbors, fish feed company agents and NGO employees. In contrast, a variety of different sizes of ponds could be seen in Brigarila. 75\% of the surveyed people in Brigarila had no proper training before starting fish farming and they just about dived into it seeing as it brought success to other people in the village (Fig. 6).

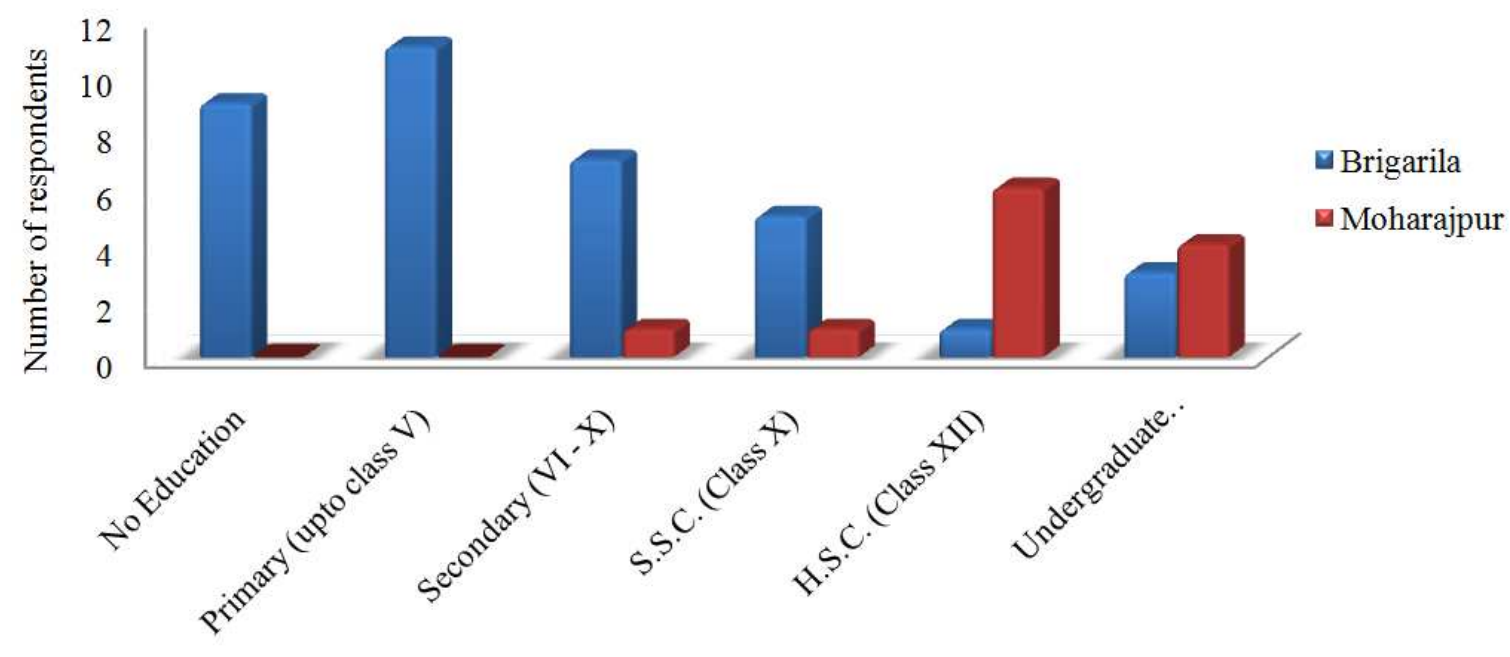

Fig. 5: Education level: Brigarila vs. Moharajpur
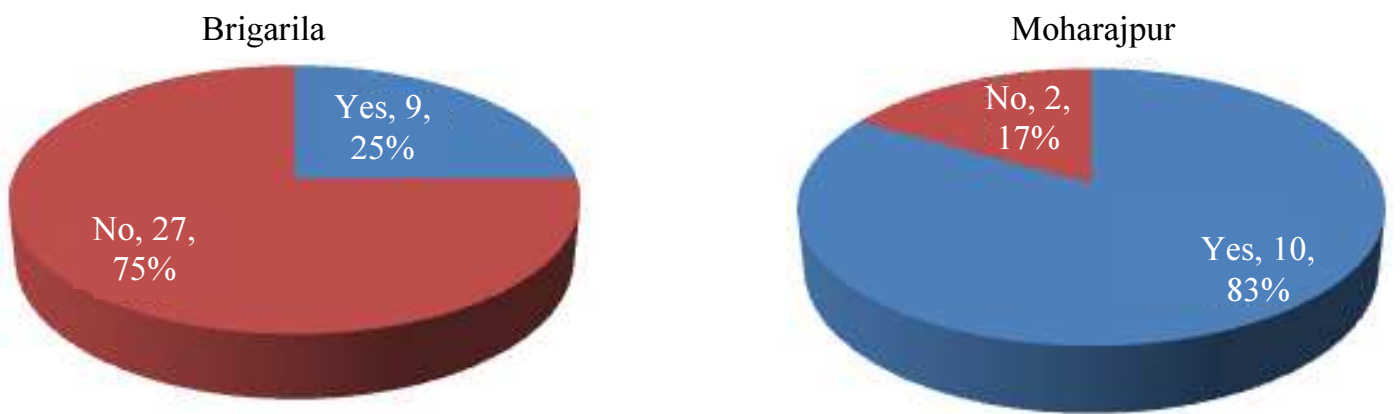

Fig. 6: Training level: Brigarila vs. Moharajpur 
Lastly, the people in Moharajpur have come up with a solution for water logging on their own, where they cut up the sides of the muddy road to build drains that runs throughout the entire main road of the village and passes into a canal that flows into the river. This has proved to be a solution for their water logging problems. This drain was a community effort and government officials had visited to check on the ingenious solution of the villagers. So, it seems that the higher education, greater experience and better training have given Moharajpur an edge over Brigarila.

\section{Recommendations:}

- Monitoring and training fish farmers would be a first step in the right direction

- Before such regions are left in a dire situation it is important to identify the causes of these problems and implement solutions to mitigate and later eradicate the issues through participatory and regulatory approaches

- With further case studies of similar areas of Gurudaspur, there can be a better understanding of the problems associated with aquaculture and figure out solutions to cope with these problems; as is seen from this paper that aquaculture is a huge contributor to the economy of Bangladesh and its rise cannot be dampened but it also cannot be ignored with rising environmental problems

- Establishment of more and broader canals and drainage systems are necessary; migratory routes to river and other nearby water bodies should be cleared

- Encouraging fish farmers to diversify the cultivation of fish species to improve the local biodiversity (as, at least this, unlike many other factors relating to biodiversity expansion, is in their hands)

- In-depth study to know about the aquatic ecosystem in ponds, how the present aquaculture practice influencing the soil and water profile

\section{Conclusion}

Aquaculture practices in Gurudaspur were a positive inception providing higher profits and improved lifestyles, but its progression has been flawed and the problems discussed above are becoming more evident every day. Moharajpur's water-logging problem is not that severe, due to their ingenuity in coming up with a suitable solution, but Brigarila's condition is much worse. It has taken Moharajpur years to reach a point where the aquaculture practices can be considered somewhat sustainable, but Brigarila might not have that long and the economics of scale might soon run out and this practice might not yield anymore profits if the vast land use change is not controlled, along with proper training and monitoring by the government.

\section{Acknowledgement}

We, the authors, are firstly grateful to the Almighty and our family and friends for the strength, support and encouragement we received from them throughout the course of the project.

Secondly, we would like to thank the Environmental Science and Management department of North South University for the opportunity to initiate and conduct the project. Thirdly, Ms. Farah Yeasmin's family, our liaison to Natore's Gurudaspur deserves a big thanks from us as without them accessibility to the areas and its residents would be an issue.

Lastly, we would like to express our immense gratitude towards the respondents of the surveys, because without them this research would be impossible.

\section{Authors' Contributions}

Saman Saad: Data collection, data processing and writing.

Raisa Bashar: Data analysis, writing and compilation.

Farah Yeasmin: GIS analysis.

Nazmul Ahsan Khan: Supervision and preparation for publication.

\section{Ethics}

There are no ethical issues associated with this paper as the key informants remain anonymous and the farmers who contributed data/information did so in full consciousness of the fact of what the research was about.

\section{References}

Bayes, A., 2015. Boosting pond fish production. Financial Express.

Faruk, M.A.R., M.J. Alam, M.M.R. Sarker and M.B. Kabir, 2004. Status of fish disease and health management practices in rural freshwater aquaculture of Bangladesh. Pak. J. Biol. Sci., 7: 2092-2098. DOI: 10.3923/pjbs.2004.2092.2098

Flowra, F.A., M.A. Islam, S.N. Jahan, M.A. Hussain and M.M. Alam et al., 2013. Status and decline causes of fish diversity of Baral River, Natore, Bangladesh. Aquac. Aquarium Conserv. Legislat. Int. J. Bioflux Society, 6: 352-357.

Jahan, K.M., B. Belton, H. Ali, G.C. Dhar and I. Ara, 2015. Aquaculture technologies in Bangladesh: An assessment of technical and economic performance and producer behavior. WorldFish Program Report, Penang, Malaysia.

James, S.D., 2009. Aquaculture production and biodiversity conservation. BioScience, 59: 27-38. DOI: $10.1525 /$ bio.2009.59.1.7 
MOP, 2013. District statistics 2011: Natore. Ministry of Planning, Bangladesh Bureau of Statistics. http://bbs.gov.bd

Toufique, K.A. and B. Belton, 2014. Is aquaculture propoor? Empirical evidence of impacts of fish consumption in Bangladesh. World Dev., 64: 609-620. DOI: 10.1016/j.worlddev.2014.06.035
Uddin, M.T. and K. Akhi, 2014. Pond fish farming under NGO support and individual management: A comparative socioeconomic study. Agriculturists, 12: 75-84. DOI: 10.3329/agric.v12i1.19584 